\title{
THE LANGUAGE LABORATORY IN FINLAND
}

\section{by Pirkko Lindquist}

Historically and culturally, Finland has made its mark: most Americans are aware nowadays that it is part of Scandinavia. The Finnish language is less well-known. Finnish does not belong to the same North Germanic group as the languages of the neighboring Scandinavian countries Sweden, Denmark, Norway and Iceland. Nor is it related to Russian, despite geography. It belongs instead to the Finno-Ugric group of languages, which ircludes Esthonian, Hungarian and a few other minority languages.

This linguistic isolation means that language teaching is important throughout the school system. Since Finnish is not used elsewhere in the world as a language of instruction, teaching material meant for Finns generally has to be produced in Finland - though more could be done than is done in adapting materials produced elsewhere. Contrastive analyses have been made for the phonetic.; of English and Finnish that provide a starting point for program makers.

The language lab forced its way into the schools of Finland's 4.5. million people at the end of the 60's. I say "forced" because reactions to the newcomer have often been emotional and negative. ("We've. managed all right without it so far.") Nevertheless, by now most tertiary level schools and colleges have labs. In the primary and secondary schools, there are about 60 full labs all told, most of these in private schools, but, strangely, only half a dozen AA and AP labs. On principle, of state schools demonstration schools are equipped first and an attempt is also made to distribute equipment evenly throughout the country. Domestic production of an AA lab. is currently under discussion. Procuring equipment doesn't seem the biggest problem. We've gradually learne.d about chains and weak links; the whole teaching process has to be good - equipment and premises, integration with other teaching, teaching and other personnel, programs. Many of these problems call for cooperation between teach. ers and administrators.

A small country can well create bodies for cooperative work, and Finland's Ministry of Education has done so, with the appointment in 1969 of the Committee for the General Planning of University-level Language Laboratory Teaching still at work today. A few remark:; are made in the following about the projects this Committee has planned and realized at the university level. The same kind of work is being done for schools at the primary and secondary level. It is planned that in addition to programs produced by private publishers 


\section{Language Lab Finland}

and groups of teachers sponsored by the Department of Public Education, the state-owned radio and television company will serve to provide language programs to primary and secondary schools.

An English version of the Committee's first report was published in 1972. "Specifications for the planning, dimensioning and use of language laboratories." It can be ordered from Ministry of Education, Department of Higher Education and Research, Helsinki. We were surprised to find, when we began, that there was no information available from other countries that would have covered all the ground we thought necessary, so that part of the report is original work. Its 130 pages include: 1 . The demand for language lab teaching (based on estimates for the 70's), 2. Technical equipment of LL, 3. LL premises, 4. Technical specifications concerning LL premises and furnishings, 5. Staff and administration of LL, 6. Instruction and study in a LL. The report provides information of many kinds and has been observed to help out in the planning of new universities. The Finnish language edition has run into a second edition, indicating that there is a need for such things.

In 1970 , the Committee appointed a working subcommittee to perform two tasks. First, to compile a handbook of language lab program making. Second, to make programs for teaching English at university level; here, author's copyright was the thorniest problem, still largely unresolved.

Independently, programs and tests are being developed at the University of Turku, using the university's computer for diagnostic and feedback purposes. Reports on the project, Black-Kohonen The University Language Laboratory (1971-2) are available from the Department of English. University of Turku. This work of Colin Black and his associates is the first of its kind in Finland. The country's University Research Computer Center in Helsinki could allow many universities to participate in this research.

At present the Turku programs in advanced-level spoken English comprise:

Pronunciation trouble-shooting (13 programs)

Intonation (10 programs)

Listening Comprehension (24 programs)

Grammatical structures (16 programs)

A series of oral composition programs is being developed.

The programs are either fully or semi programmed self-instructional materials. Some sample frames from an intonation program: ${ }^{1}$

'Colin Black, Practising English Intonaticn, pp. 62-65. Pub. Co., Helsinki 1972. 


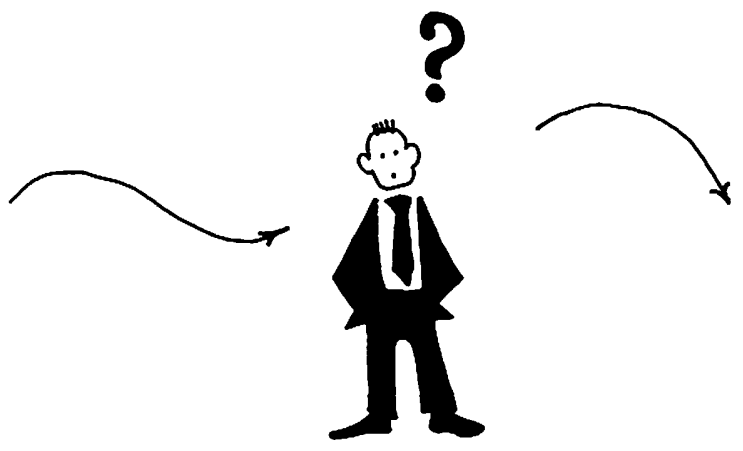

The basic intonation of Finnish is a falling intonation.

For this reason, there is a danger that a Finnish person speaking Inglish will alwars use the falling twe.

And this means that he will often appear unfriendly to an English listener.

\section{Exercise.}

Listen to these statements.

Bach will be spoken onec, either in a friendly way or in a matter of fact way.

If you think it is friendly, put a cross in the box marked $F . \quad x$ If you think it is matter of fact, put a cross in the box marked $M . X$

Example.

I'll think about it.

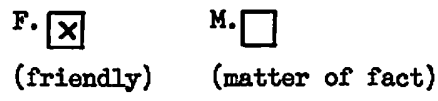

The intonation was friendly,

so there is a cross in the box marked $F$.

TORN THE PAGE QUICKII

Listen to the example again. Now begin.

Käännä nopeasti: 


\section{Language Lab Finland}

I'II think about it.

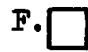

$M \cdot \square$

There's no need to worry.
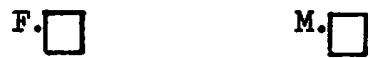

There's plenty of time.
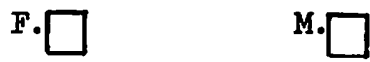

I'll see if I can help you.
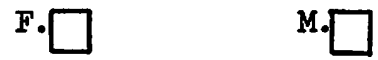

I hope you'll do your best.
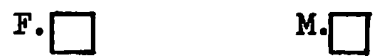

You can see me later.
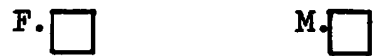

Repeat these sentences.

They are all matter of fact.

There's no need to worry.

There's plenty of time.

I hope you'll do your best.

Repeat these sentences.

They are all friendly.

I'll think about it.

I'll see if I can help you.

You can see me later. 
The Ministry's committee has commissioned further programs in Swedish and German. Lack of clear and specific instructional objectives has greatly hampered this work, which has to rely too much on guesswork. Groundwork on language teaching objectives is now accepted as part of the Committee's task.

Another great difficulty is getting teachers to take an interest in the programs mado for them. For years, teachers have been complaining that there are no programs; when programs are made, they show little interest. The following comment was a typical reaction: "We regret that, owing to lack of time, we have not been able to make a close examination of all the tapes and accompanying texts that were sent to us."

Among the Committee's plans for the near future are further program production, detailing instructional objectives, initiating distribution of information for university language labs and setting up a possible language lab center. This last seems the central issue: we hope for an active and creative center, not another bureaucratic unity. All that is needed is to extend the work of some actively functioning lab by freeing it from restrictions of money and personnel. The center would be a distributor of information and a provider of impulse. To further develop programs and tests, it would be necessary for part of the center to be actively engaged in teaching. Until these plans are realized, every university in the country should be developing its lab's personal and material resources so that a future center can be guaranteed feedback from the universities.

ABOUT THE AUTHOR:

Pirkko Lindquist, M.A. is in charge of the language lab at the University of Turku, Finland. 